Original article

\title{
LiDAR derived ecological integrity indicators for riparian zones: Application to the Houille river in Southern Belgium/Northern France
}

\author{
Adrien Michez ${ }^{\mathrm{a}, *}$, Hervé Piégay ${ }^{\mathrm{b}}$, François Toromanoff ${ }^{\mathrm{a}}$, Delphine Brogna ${ }^{\mathrm{c}}$, \\ Stéphanie Bonnet ${ }^{\mathrm{a}}$, Philippe Lejeune ${ }^{\mathrm{a}}$, Hugues Claessens ${ }^{\mathrm{a}}$ \\ a University of Liege, Gembloux Agro-Bio Tech, Department of Forests Nature and Landscape, Unit of Forest and Nature Management, 2 Passage des \\ Déportés, 5030 Gembloux, Belgium \\ ${ }^{\mathrm{b}}$ University of Lyon, UMR 5600 CNRS EVS, Site ENS, 15 Parvis R. Descartes, BP 7000, 69362 Lyon Cedex 07, France \\ ' University of Namur, Department of Geography, Rue de Bruxelles 61, 5000 Namur, Belgium
}

\section{A R T I C L E I N F O}

\section{Article history:}

Received 10 April 2013

Received in revised form 13 June 2013

Accepted 20 June 2013

\section{Keywords:}

LiDAR

Ecological integrity indicator

Riparian corridor

Riparian mapping

Network

\begin{abstract}
A B S T R A C T
Riparian zones are central landscape features providing several ecosystem services and are exceptionally rich in biodiversity. Despite their relatively low area coverage, riparian zones consequently represent a major concern for land and water resource managers confirmed within several European directives. These directives involve effective multi-scale monitoring to assess their conditions and their ability to carry out their functions. The objective of this research was to develop automated tools to provide from a single aerial LiDAR dataset new mapping tools and keystone riparian zone attributes assessing the ecological integrity of the riparian zone at a network scale $(24 \mathrm{~km})$.

Different metrics were extracted from the original LiDAR point cloud, notably the Digital Terrain Model and Canopy Height Model rasters, allowing the extraction of riparian zones attributes such as the wetted channel ( $0.89 \mathrm{~m}$; mean residual) and floodplain extents (6.02 $\mathrm{m}$; mean residual). Different riparian forest characteristics were directly extracted from these layers (patch extent, overhanging character, longitudinal continuity, relative water level, mean and relative standard deviation of tree height). Within the riparian forest, the coniferous stands were distinguished from deciduous and isolated trees, with high accuracy (87.3\%, Kappa index).

Going further the mapping of the indicators, our study proposed an original approach to study the riparian zone attributes within different buffer width, from local scale (50 m long channel axis reach) to a network scale (ca. $2 \mathrm{~km}$ long reaches), using a disaggregation/re-agraggation process. This novel approach, combined to graphical presentations of the results allow natural resource managers to visualise the variation of upstream-downstream attributes and to identify priority action areas.

In the case study, results showed a general decrease of the riparian forests when the river crosses built-up areas. They also highlighted the lower flooding frequency of riparian forest patches in habitats areas.

Those results showed that LiDAR data can be used to extract indicators of ecological integrity of riparian zones in temperate climate zone. They will enable the assessment of the ecological integrity of riparian zones to be undertaken at the regional scale $(13,000 \mathrm{~km}$, completely covered by an aerial LIDAR survey in 2014).
\end{abstract}

(C) 2013 Elsevier Ltd. All rights reserved.

\section{Introduction}

Naiman et al. (2005) defined the riparian zone as "transitional semi-terrestrial areas regularly influenced by fresh water, normally extending from the edges of water bodies to the edges of upland communities". Riparian zones are central landscape features supporting several functions and services: stream bank stabilisation,

\footnotetext{
* Corresponding author. Tel.: +32 474690657 .

E-mail address: adrien.michez@gmail.com (A. Michez).
}

reduction of sediment and nutrient contamination, aquatic and terrestrial habitat improvement, and recreational and educational opportunities (Malanson, 1993). As ecotones located at the intersection of land and water, riparian zones are exceptionally rich in biodiversity (Naiman and Décamps, 1990; Naiman et al., 1993). They represent ecological corridors (Rodriguez-Iturbe et al., 2009) and provide a crucial habitat for terrestrial animals and for migrating birds (Hilty and Merenlender, 2004; Machtans et al., 1996; Skagen et al., 1998, 2005). The width of a zone can range from a few metres to several kilometres. It depends on the stream size and the position of the zone within the watershed, as well as on 
the hydrological regime and the local physical configuration. Hence their relatively low area coverage, riparian zones consequently represent a major concern for land and water resource managers.

In Europe, the major importance of riparian zones has been acknowledged in several European directives (principally the Habitats Directive and the Water Framework Directive). These directives involve effective multi-scale monitoring (local to network scales) to target restoration activities when needed and to assess the success of previous management actions or existing management policies (European Council, 2000). Riparian zones monitoring is based on measurable attributes describing the riparian zone conditions and their ability to carry out their functions. As example, the longitudinal continuity is important for plant dispersal (Johansson et al., 1996; Hughes, 2003), production of stream insects (Hannon et al., 2002; Whitaker et al., 2000) or migration of birds (Decamps et al., 1987; Tewksbury et al., 2002) and mammals (Darveau et al., 2001; Cockle and Richardson, 2003). Monitoring often combines observable physical, chemical and biological attributes, which can vary in response to human alteration. When responding in a known way to alteration or improvement, an attribute can be considered as an indicator, which can be used to establish a given assessment - e.g. the ecological integrity. Ecological integrity is defined as the capacity to support and maintain a balanced, integrated and adaptive biological system having the full range of elements and processes expected in a region's natural habitat (Karr and Dudley, 1981). For riparian zones, Innis et al. (2000) proposed five categories of indicators (micro-climate, patch heterogenity, biodiversity, terrestrialization, seston) as integrative indicators of ecological integrity. Because of the typical shape of the riparian zone, field based monitoring of these zones involves high manpower costs and timeconsuming travel (Myers, 1989; Platts et al., 1987). Therefore the sampling intensity and thus the accuracy of results are reduced. Because of these limitations, aerial photo interpretation of riparian attributes carried out by operators has been explored (Booth et al., 2007; Congalton et al., 2002; Fensham and Fairfax, 2002). However, this operator-based method remains time-consuming process and faces the same limitations as field based approaches.

Numerous references can be found about riparian zone description based on remote sensing techniques (Table 1 ), developing both automated classification and interpretation-by-operator approaches. Most of the previous studies have been based on aerial photo interpretation, but the increasing availability of very high resolution satellite imagery (IKONOS, QuickBird and GeoEye-1) and aerial LiDAR data, more powerful computer capacity and new geomatic procedures to extract information offer opportunities to develop cost effective, replicable and fully automated riparian zone monitoring at channel corridor to network scales.

The high density point clouds of LiDAR data can provide a 3D view of the features of a floodplain and notably of riparian zone characteristics. Most of the previous studies found in the literature on the use of LiDAR data in riparian zone (see Table 2) relate to topographic and geomorphic applications (Colson et al., 2006; Hilldale and Raff, 2008; Höfle et al., 2009; Hohenthal et al., 2011; Kinzel et al., 2007; Notebaert et al., 2009). Previous studies also show the potential of LiDAR data to describe riparian vegetation; but most of these are focused on forest applications (Farid et al., 2006, 2008; Greenberg et al., 2012; Wasser et al., 2013). Only a few studies can be found on the potential of LiDAR data to describe the ecological attributes of riparian zone (Hall et al., 2009; Johansen et al., 2010).

Following these pioneer studies, which focused on the algorithmic detection of riparian attributes, a synthetic characterisation considering simultaneously riparian zone attributes at different lateral scales (from wetted channel to entire floodplain) and longitudinal scales has not yet been proposed.

In this study we combined aerial LiDAR, OBIA (eCognition Developer) and classic GIS (ArcInfo toolboxes) to develop new automated

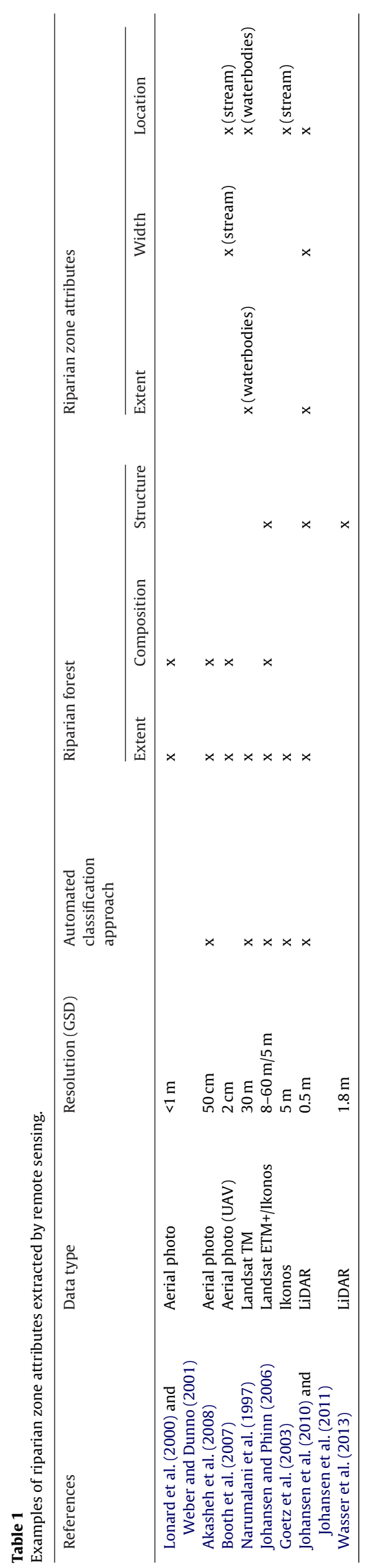


Table 2

Review summary of riparian zone attributes extracted from LiDAR data in the literature.

\begin{tabular}{|c|c|c|c|}
\hline Parameter type & Parameter & Country & References \\
\hline \multirow[t]{2}{*}{ River morphology } & Water surface mapping & Austria & Höfle et al. (2009) \\
\hline & Stream bed extent, riparian zone extent & Australia & Johansen et al. $(2010,2011)$ \\
\hline \multirow[t]{4}{*}{ Riparian forest attributes } & $\begin{array}{l}\text { Tree height, crown diameter, canopy } \\
\text { closure and vegetation density }\end{array}$ & Turkey & Dowling and Accad (2003) and Akay et al. (2012) \\
\hline & Age class & USA & Farid et al. (2006) \\
\hline & Stream shading & USA, Australia & $\begin{array}{l}\text { Johansen et al. (2010), Greenberg et al. (2012) } \\
\text { and Wasser et al. (2013) }\end{array}$ \\
\hline & $\begin{array}{l}\text { Longitudinal continuity, overhanging } \\
\text { vegetation, large trees }\end{array}$ & Australia & Johansen et al. (2010) \\
\hline
\end{tabular}

tools for mapping stream channels and riparian zones and for measuring key attributes to assess the ecological integrity of riparian zones. We used a $35 \mathrm{~km}$ section of the Houille River, a tributary of the Meuse (Belgium), as a model system in the method development. As the entire area of Wallonia (Belgium) will be soon covered by a LiDAR dataset, this pilot study was designed to test procedures allowing riparian zone characterisation for assessing the ecological integrity of riparian zone at the scale of the entire Walloon region (average $17,000 \mathrm{~km}^{2}, 13,000 \mathrm{~km}$ of watercourses) by the public watercourses manager. In the present study, we investigated different LiDAR derived riparian zone attributes, considered as indicator of the ecological integrity of riparian zone (Table 3). These LiDAR derived indicators describe riparian forest planimetric characteristics (patch extent, overhanging character) and conditions (longitudinal continuity, coniferous stand detection, mean height and relative standard deviation, relative water level). Two major physical settings were also investigated by the mapping of the wetted channel and floodplain extents.

\section{Materials and methods}

\subsection{Study site}

The study site was located in the cross-border valley of the river Houille (Fig. 1), a tributary of the river Meuse in the French and Belgian Ardennes. Analyses were performed on the Houille river downstream from Gedinne (Wallonia, Belgium) to its confluence with the Meuse in Givet (France). The Houille river catchment represents more than $50 \mathrm{~km}^{2}$ at Gedinne, and $240 \mathrm{~km}^{2}$ at the Meuse confluence. Forest (61\%) and pasture (24\%) are the major land uses of the catchment area.

Floodplain width along this $24 \mathrm{~km}$ section (valley length) ranges from 55 to $540 \mathrm{~m}$. Average river width and slope are $8 \mathrm{~m}$ and $0.6 \%$, respectively. The channel is sinuous, occasionally meandering, with steep banks and a single-thread pattern with emerged bars.

Mean annual river discharge is $1.13 \mathrm{~m}^{3} / \mathrm{s}$ at the gauging station in Gedinne (Belgium, $35 \mathrm{~km}$ from the confluence 1992-2012). During the vegetative period (March to September), the mean daily discharge varied from 0.15 (in 2011) to $0.92 \mathrm{~m}^{3} / \mathrm{s}$ (in 2012), representing a variation in water elevation (at the gauge) of $0.17 \mathrm{~m}$ (Eau France, 2012; Service Public de Wallonie, 2012). The 1 in 2 year and 1 in 10 year floods are respectively estimated to be 8 and $15 \mathrm{~m}^{3} / \mathrm{s}$ at Gedinne (daily flow series 1992-2012).

\subsection{Acquisition of remote sensing data}

An aerial small footprint LiDAR dataset covering the whole watershed was captured on March 2011 (leaf-off dataset) at a discharge of $0.6 \mathrm{~m}^{3} / \mathrm{s}$ at the Gedinne gauging station. We used a "Riegl LMSQ680" sensor, with an average point density of 13 points $/ \mathrm{m}^{2}$. The LiDAR returns were classified as "ground", "vegetation", "building", "water" or "unclassified" by the data provider using proprietary software and according to the LAS standard format. The dataset was stored in tiled $(500 \mathrm{~m} \times 500 \mathrm{~m})$ ".las" files.

Table 3

LiDAR derived riparian zone attributes as indicators of ecological functionality/integrity.

\begin{tabular}{|c|c|c|c|c|c|c|}
\hline \multirow[t]{2}{*}{ Riparian zone attributes } & \multirow[t]{2}{*}{ Indicator of ecological function } & \multicolumn{5}{|c|}{ Indicators of ecological integrity (Innis et al., 2000) } \\
\hline & & $\begin{array}{l}\text { Micro- } \\
\text { climate }\end{array}$ & $\begin{array}{l}\text { Patch het- } \\
\text { erogenity }\end{array}$ & Biodiversity & Terrestrialization & Seston \\
\hline \multicolumn{7}{|l|}{ Riparian forest } \\
\hline Longitudinal continuity & $\begin{array}{l}\text { Corridors for plant dispersal (Johansson et al., 1996; } \\
\text { Hughes, 2003) } \\
\text { Habitats and migration corridors for birds (Decamps et al., } \\
\text { 1987; Tewksbury et al., 2002) and mammals (Cockle and } \\
\text { Richardson, 2003; Darveau et al., 2001) }\end{array}$ & $\mathrm{x}$ & $\mathrm{x}$ & $\mathrm{x}$ & & $\mathrm{x}$ \\
\hline Height (mean, relative SD) & $\begin{array}{l}\text { Mature stand localisation (mean height); spatial } \\
\text { heterogeneity (relative SD) is linked to species richness } \\
\text { (Naiman et al., 2005; Pollock et al., 1998) }\end{array}$ & & $\mathrm{x}$ & $\mathrm{x}$ & & \\
\hline Coniferous stand detection & $\begin{array}{l}\text { Reducing bank stability and biodiversity in riparian areas } \\
\text { (Petit, 1992; Piégay et al., 2003; Schneider, 2007) }\end{array}$ & & $\mathrm{x}$ & $\mathrm{x}$ & $\mathrm{x}$ & $\mathrm{x}$ \\
\hline Overhanging character & $\begin{array}{l}\text { Shading effect and water temperature regulation services. } \\
\text { Also offers habitat and organic input to benthic fauna } \\
\text { (Barton et al., 1985; Beschta et al., 1987; Shirvell, 1990) }\end{array}$ & $\mathrm{x}$ & & $\mathrm{x}$ & & \\
\hline Relative water level & $\begin{array}{l}\text { Flooding frequency of riparian zone, central habitat } \\
\text { attribute for typical riparian species (Naiman et al., 2005; } \\
\text { Pollock et al., 1998) }\end{array}$ & & $\mathrm{x}$ & $\mathrm{x}$ & $\mathrm{x}$ & \\
\hline \multicolumn{7}{|l|}{ Physical settings } \\
\hline Floodplain extent (width) & Structural feature of riparian zone; Provides habitats and & & & & $\mathrm{x}$ & \\
\hline Wetted channel extent (width) & $\begin{array}{l}\text { migration corridors for riparian species communities (Del } \\
\text { Tánago and de Jalón, 2006; Naiman et al., 2005) }\end{array}$ & & $\mathrm{x}$ & & $\mathrm{x}$ & \\
\hline
\end{tabular}




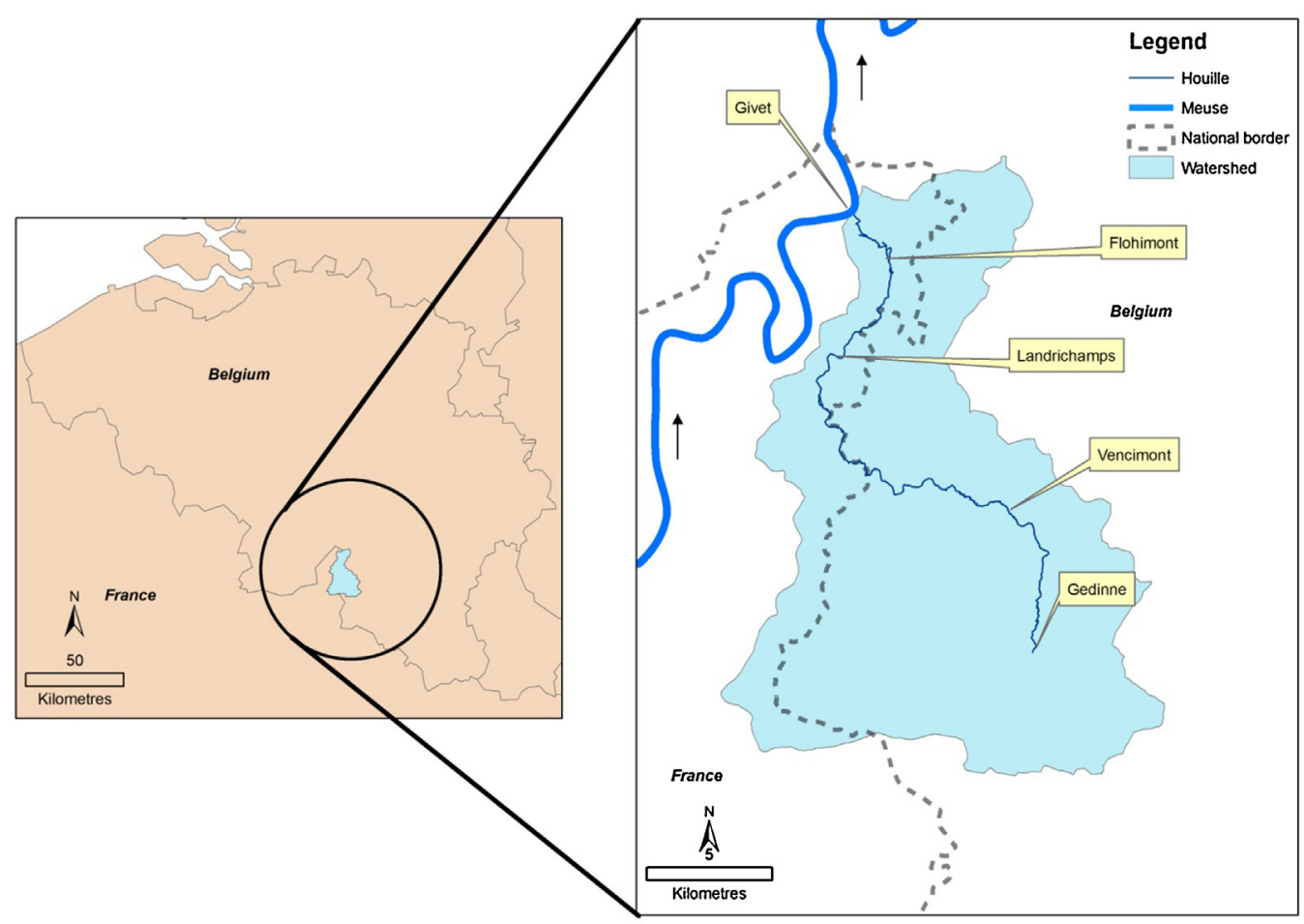

Fig. 1. Localisation of the Houille basin at the Belgium/France border and the reach studied within the basin (main localities in text boxes).

An orthophoto of the channel reach was also acquired with an aerial photo dataset captured on July 2011 using a "Vexcel UltraCamX" camera with a spatial resolution of $0.25 \mathrm{~m}$.

\subsection{LiDAR data pre-processing}

The LiDAR point cloud was initially processed with the software "Las2Pix", developed by the Unit of Forest and Nature Management (University of Liege - Gembloux Agro-Bio Tech). This software allows the extraction of LiDAR derived raster metrics from original ".las" files. Eight major metrics were initially derived from the LiDAR data (Fig. 2) and were analysed using both OBIA and classic geomatic tools.

A first Digital Terrain Model (DTM) was extracted from the original point cloud by the service provider and was interpolated by an ArcGIS routine using a $3 \times 3$ moving window with a pixel size of $1 \mathrm{~m}$. The Digital Surface Model (DSM) was extracted from the most elevated returns and was compiled in a $0.5 \mathrm{~m}$ raster. The Canopy Height Model (CHM) raster (pixel size $0.5 \mathrm{~m}$ ) was produced by subtracting the interpolated DTM from the DSM. Two "Intensity" rasters were produced with Las2Pix with a pixel size of $0.5 \mathrm{~m}$ and were interpolated with the same ArcGIS routine. For each pixel, the mean intensity value of the LiDAR point cloud was calculated for all returns (Intensity "all returns" raster) and for the points pre-classified as "vegetation" (Intensity "vegetation" raster).

Three "Number of returns" rasters were also extracted with Las2Pix, computing the number of returns per pixel of $0.5 \mathrm{~m}$ for three classes of the point cloud: "building", "water", "ground".

\subsection{Extraction of attributes characterising the riparian zone}

Based on the different metrics extracted from the LiDAR point cloud, the following riparian zone and floodplain attributes were extracted with OBIA and classic GIS tools found in ArcToolbox (Table 4).

\subsubsection{Physical settings}

By mapping the wetted channel of the Houille, the aim was to localise the water-land boundary, along the studied river, for $0.6 \mathrm{~m}^{3} / \mathrm{s}$ at Gedinne. The high absorption of near-infrared LASER

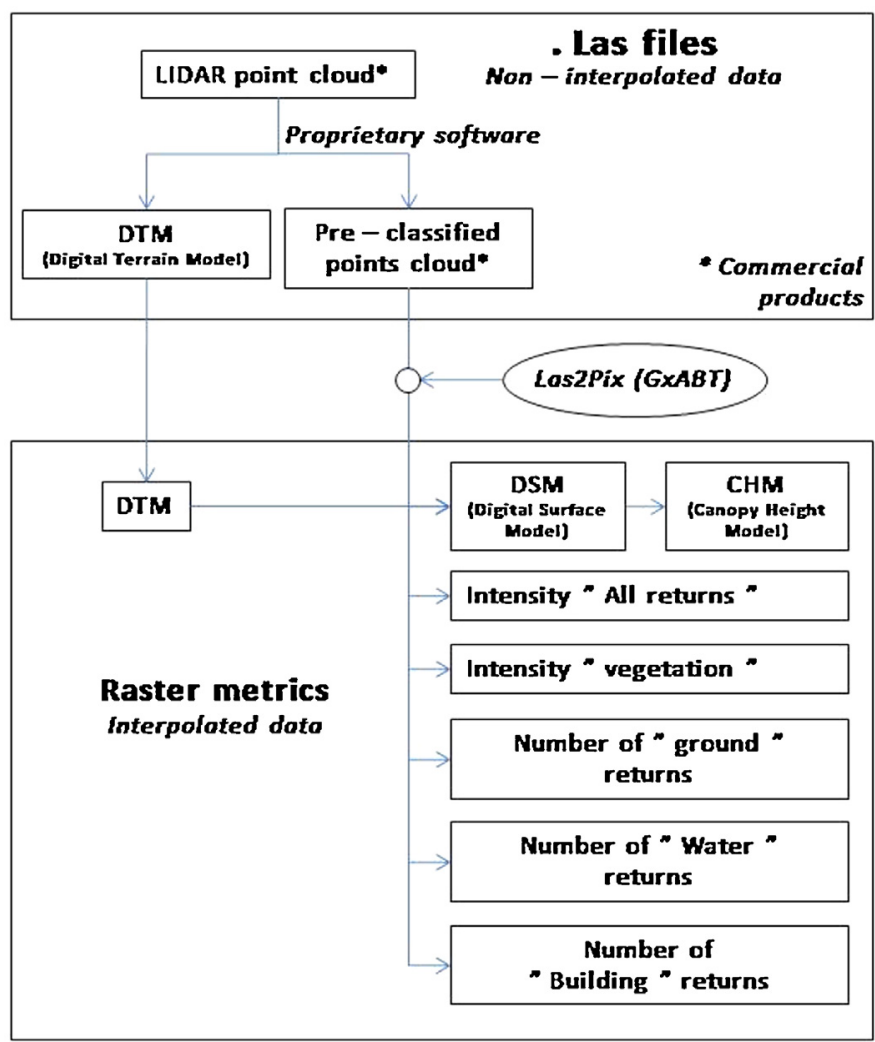

Fig. 2. Flow chart describing the LiDAR data pre-processing with Las2Pix from initia LiDAR point cloud and non-interpolated DTM. 
Table 4

Riparian zone attributes derived from LiDAR; LiDAR metrics \& GIS tools used.

\begin{tabular}{|c|c|c|c|}
\hline \multirow[t]{2}{*}{ Riparian zone attribute } & \multirow[t]{2}{*}{ Metrics used to map the attribute } & \multicolumn{2}{|c|}{ GIS tools used } \\
\hline & & OBIA & Classic GIS tools \\
\hline Wetted channel extent & Number of returns rasters (“water”, “ground”); DTM & $\mathrm{X}$ & \\
\hline Floodplain extent & DTM & & $\mathrm{X}$ \\
\hline Riparian forest patches & CHM, number of "building" returns & $\mathrm{X}$ & \\
\hline Riparian forest longitudinal continuity & CHM, number of "building" returns & $\mathrm{X}$ & \\
\hline Overhanging vegetation & Wetted channel extent; riparian forest patches & & $\mathrm{X}$ \\
\hline Evergreen coniferous stand detection & CHM, number of "building" returns, Intensity "vegetation" raster & $\mathrm{X}$ & \\
\hline Mean and relative SD of tree height & CHM, "riparian forest patch" layer & & $\mathrm{X}$ \\
\hline Riparian forest relative water level at the time of survey & Relative DTM; riparian forest patches & & $\mathrm{X}$ \\
\hline
\end{tabular}

by the wetted channel resulted in very low point densities locally. Nevertheless, some returns were obtained from woody debris or gravel bed, pre-classified as "water" by the service provider. In accordance with the work of Höfle et al. (2009), the methodology developed here takes advantage of those very low point density areas in the LiDAR point cloud by localising them in a "Number of 'ground' returns" raster (Fig. 3). After an initial segmentation process based on the "Number of 'ground' returns" raster, the ruleset developed in eCognition focuses on the discrimination of "river object" rather than other low point density objects (e.g. other water bodies, wood piles).

In order to map the floodplain extent, we used the methodology developed by Alber and Piégay (2011), which regards the valley bottom "as a submerged floodplain for a uniform waterflow height". Based on the LiDAR derived interpolated DTM (see Fig. 2), an altimetric reference plan (Fig. 3) was produced and sampled in transects, distributed regularly (at 50-m intervals) along a director axis derived by smoothing the centreline of the previously extracted wetted channel layer. The altimetric reference plan was then subtracted from the absolute DTM to produce a relative DTM in relation to the channel elevation at each point along the stream network. Areas under the $3 \mathrm{~m}$ threshold were extracted and converted into a polygon format (Fig. 3C). The floodplain extent was obtained after a simple ArcGIS cleaning treatment ("aggregate polygon") of the resulting polygon. In this case, we used a threshold of $3 \mathrm{~m}$ (rather than $10 \mathrm{~m}$ as in Alber and Piégay (2011) case study), based on historical maxima discharge observed at the gauging station at Gedinne, Belgium.

\subsubsection{Disaggregation and re-aggregation process}

Based on the work of Alber and Piégay (2011), a disaggregation procedure was used to characterise the variation of attributes from
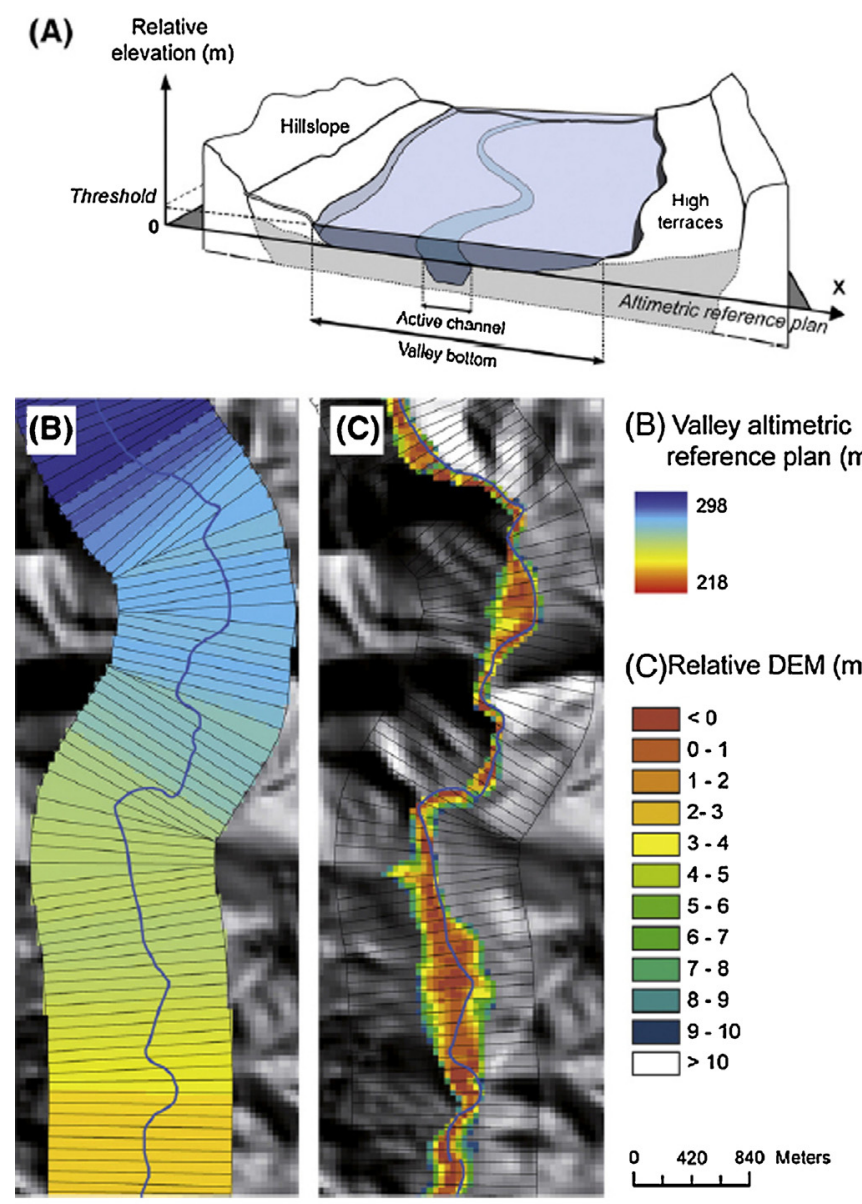

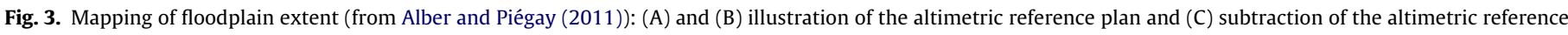
plan from the absolute DTM gives the relative DEM. 


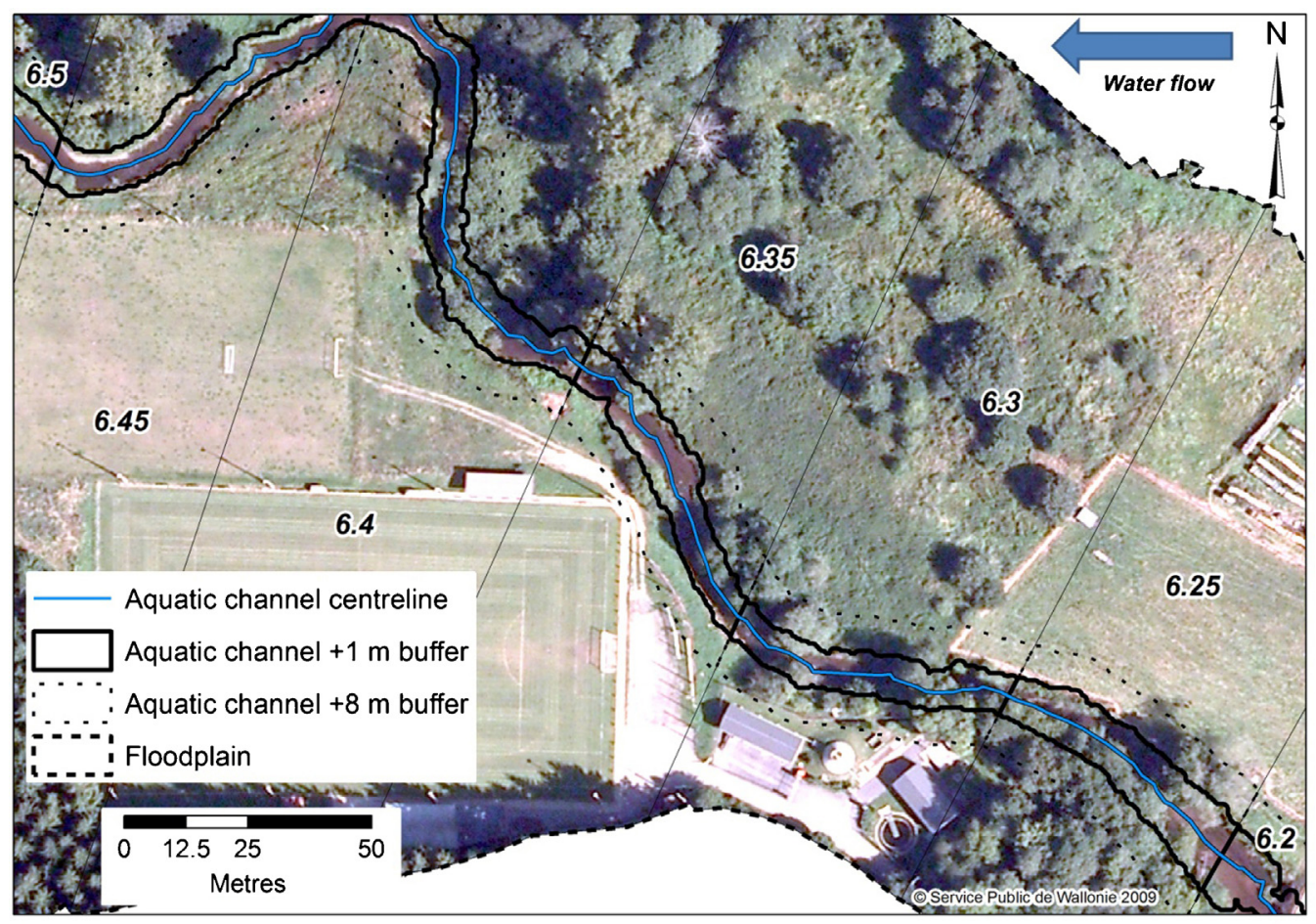

Fig. 4. Longitudinal sampling of $50 \mathrm{~m}$ long segments and of lateral sampling buffers.

upstream to downstream. The analysis was performed within each floodplain sample developed during the construction of the relative DEM (Fig. 3B and 4). The results were presented graphically to enable the identification of upstream-downstream patterns. When appropriate, an upstream-downstream analysis was performed at different lateral scales: left-right bank, wetted channel plus 1 and $8 \mathrm{~m}$ riparian buffers, and entire floodplain (Fig. 4).

After this disaggregation process, a re-aggregation process could be performed, analysis at the sample scale $(50 \mathrm{~m}$ long channel axis reach) being computed at a higher scale, e.g. at a $1 \mathrm{~km}$ channel axis reach (Fig. 5).

\subsubsection{Planimetric and intrinsic characteristics of riparian forest patches}

2.4.3.1. Riparian forest patch detection. An OBIA approach in eCognition was developed to identify the previously extracted riparian forest patches within the floodplain layer. The CHM and the leafoff "Intensity vegetation" layer were used for the segmentation. The "Number of building returns" raster was used to distinguish building objects from forest objects. Riparian forest patch objects were identified using a minimal mean object height threshold of $1.5 \mathrm{~m}$, as this threshold allows the avoidance of even tall herbaceous riparian areas in a leaf-off period.

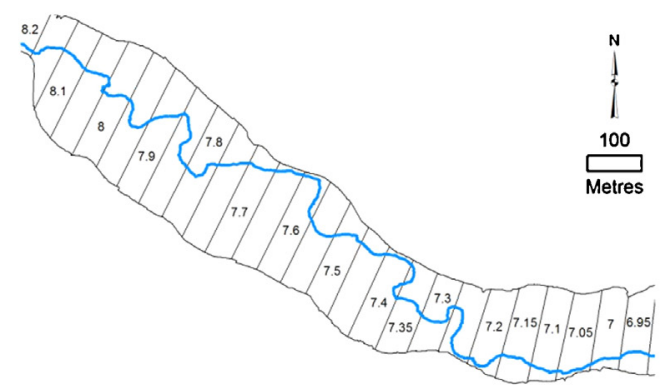

2.4.3.2. Overhanging character. An overhanging riparian forest polygon was extracted using classic geoprocessing between the "riparian forest patch" and the "wetted channel" layers.

The overhanging character of the riparian forest was investigated within each 50-m long floodplain sample segment (Fig. 4) in order to perform an upstream-downstream analysis. For a given sample, the overhanging character was estimated using two indexes, one taking into account the relative bank length (left and right distinctly) with overhanging vegetation and the other focusing on the relative wetted channel area with overhanging vegetation (Fig. 6).

Overhanging linear index (left bank) $\mathrm{Xi}=$

Left bank length with overhanging vegetation (sample $\mathrm{Xi}$ ) Left bank length (sample Xi)

Overhanging surface index $\mathrm{Xi}=$

Overhanging vegetation sample $\mathrm{Xi}$ area (sample $\mathrm{Xi}$ ) Aquatic channel sample Xi area (sample Xi)

The linear index relating to the relative bank length with overhanging vegetation is not linked to the wetted channel extent and

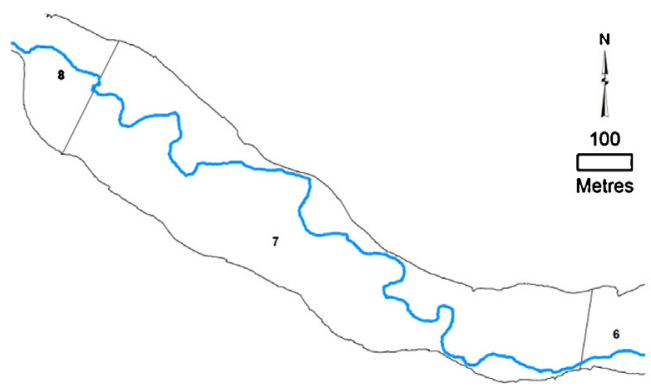

Fig. 5. Re-aggregation process: $50 \mathrm{~m}$ long disaggregated to $1 \mathrm{~km}$ long re-aggregated reaches. 


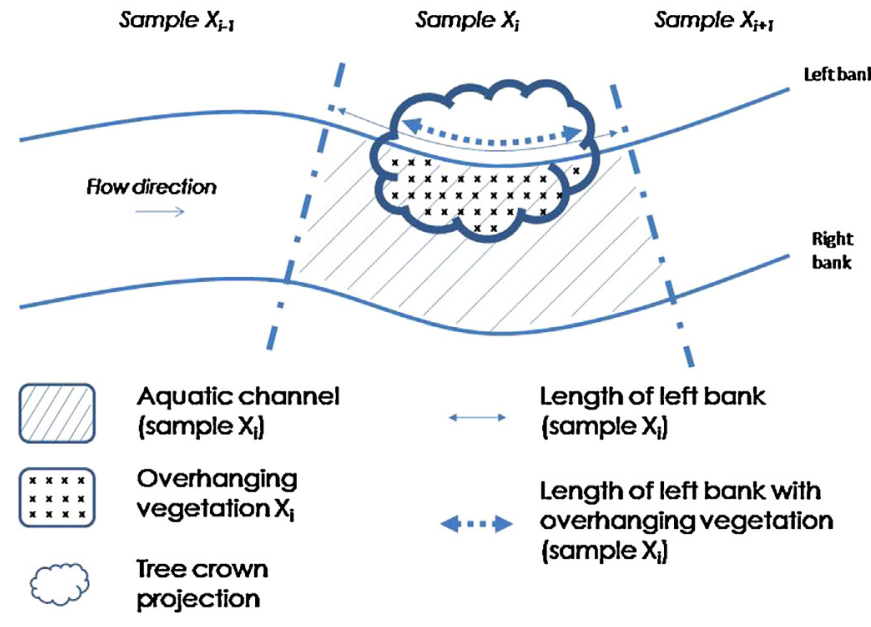

Fig. 6. Overhanging character of riparian forests measured within each $50 \mathrm{~m}$ long sample segment of the floodplain.

offers information on the presence of riparian trees very close to the water. The surface index is directly linked to the channel extent and thus gives information on the shade effect produced by riparian trees. The two overhanging indexes are complementary and can be applied to various types of river morphology.

2.4.3.3. Longitudinal continuity. The mapping of the longitudinal continuity of riparian forests can be theoretically defined as the continuity of the presence of riparian forests along a given stream network. In order to map this riparian attribute, two characteristics need to be specified: the presence of riparian vegetation and the width of the buffer along the stream network in which analyses take place.

Following the riparian forest patch detection process, objects not classified as "riparian forest patches" along the study reach were classified as gaps in longitudinal continuity when they met 3 conditions: a mean height of less than $1.5 \mathrm{~m}$, a width greater than $5 \mathrm{~m}$, and a minimal area of $50 \mathrm{~m}^{2}$. Isolated riparian forests patches with a surface area of less than $15 \mathrm{~m}^{2}$ were merged with the surrounding gaps. Small gaps that did not reach the 3 thresholds conditions were merged with riparian forest patches, considering they do not represent a meaningful gap in riparian forest continuity. This approach was adapted from Johansen et al. (2010), who used a plant projective cover layer instead of the CHM layer to map riparian forest patches in the context of a dry sub-tropical savannah.

We defined a riparian forest continuity index for each of the 50-m long sampling segments in order to explore the upstream-downstream pattern:

Continuity index sample $=1-\frac{\text { Riparian forest gap area (sample Xi) }}{\text { total area }(\text { sample } \mathrm{Xi})}$

2.4.3.4. Evergreen coniferous stands. Except for Larix sp. stands, which represent $3.6 \%$ of the coniferous stand in Wallonia (Lecomte et al., 2006), the majority of Walloon coniferous stands are evergreen. This particularity was used by an eCognition ruleset to localise the coniferous stands within the identified riparian forest patches. The segmentation process was based on the CHM and leafoff "Intensity vegetation" rasters. After localising the isolated trees from forest stands $\left(50 \mathrm{~m}^{2}\right.$ maximal area threshold combined with a neighbouring index), the classification process used the photosynthetic activity of the evergreen coniferous stands recorded during the March 2011 LiDAR data survey in order to discriminate those from broadleaved stands, which did not exhibit any photosynthetic activity.

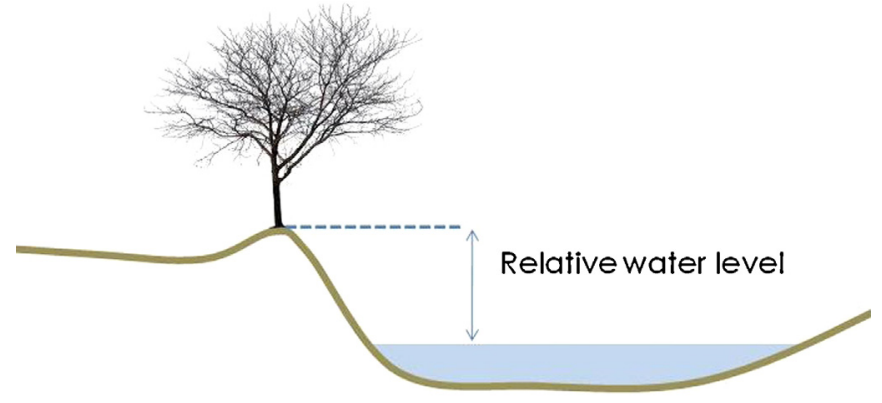

Fig. 7. Illustration of relative water level as an indicator of the nearness to water level (regarding the wetted channel) of the riparian forest.

2.4.3.5. Heights of riparian forest stands. Within the previously identified riparian forest patches, some basic statistical analysis (zonal statistics/ArcMap Toolbox) were performed (mean, relative $\mathrm{SD}$ ) on the CHM raster at the floodplain sample scale.

2.4.3.6. Relative water levels. The relative DTM built during the floodplain extent study was clipped to the riparian forest patch layer. In this new raster layer, each pixel characterised the relative water level of the riparian forest stands (Fig. 7) at a $0.6 \mathrm{~m}^{3}$ discharge.

\subsection{Validation}

Direct and indirect approaches were used for validation (Table 5). An indirect approach was applied to layers relying on previously validated layers.

The DTM validation process compared the 254 altimetric measurements to the associated DTM raster values. The field altimetric measurement database was compiled with 42 real time kinematic (RTK) GPS measurements (Leica 200+), 30 reference points from the Belgian Geographic National Institute and 182 reference points from the Walloon public data repository.

A similar approach was used for the CHM validation, comparing field data to the raster values. The height of 159 dominant broadleaved trees were measured during March and April 2012 within the watershed. Measurements were made using a fieldmap system (http://www.fieldmap.cz), initially positioned with a DGPS (GNSS Leica GPS1200+). The raster values were extracted using zonal statistics (maximal value) within a theoretical circle with a radius proportional to the area measured crown projections.

\subsubsection{Wetted channel and floodplain extent}

In order to assess the planimetric accuracy of the LiDAR derived wetted channel extent, a comparison was made by calculating the minimal distance between the field measured and LiDAR derived wetted channel extent. A negative distance value was assigned when the LiDAR derived wetted channel extent was within the field measured wetted channel extent (wetted channel extent underestimation). The classification accuracy (overall, producer and user) was also assessed. The wetted channel extent of seven reaches of the Houille river was mapped using a Total Station Leica during a period of 4 days in March 2012.

The field survey was located downstream at Gedinne (Belgium), and upstream at the French border, where good accessibility and GPS coverage were guaranteed. Ideally a field survey should be contemporaneous with the LiDAR data acquisition process. Although the field survey in the present study was not undertaken in this way, it was conducted in similar hydrological conditions (Table 6).

A similar approach was developed for floodplain layer validation, comparing the LiDAR derived floodplain extent to a field 
Table 5

Summary of layer validation approaches used.

\begin{tabular}{|c|c|}
\hline Layer & Validation approach \\
\hline DTM & Direct (224 field measurements) \\
\hline $\mathrm{CHM}$ & Direct (159 field measured tree heights) \\
\hline Wetted channel extent & Direct ( $>800 \mathrm{~m}$ (linear watercourse) of wetted channel extent mapped in the field (1418 points)) \\
\hline Floodplain extent & $>800 \mathrm{~m}$ (watercourse linear) of riparian zone extent mapped in the field \\
\hline Riparian forest patches and longitudinal continuity & Indirect (based on the validated CHM layer) \\
\hline Riparian forest overhanging character & Indirect (based on the validated CHM and wetted channel layers) \\
\hline Riparian forest height (mean; relative SD) & Indirect (based on the "riparian forest patch" layer and the validated CHM layer) \\
\hline Evergreen coniferous stands & Direct (aerial photo interpretation (300 points) and confusion matrix) \\
\hline Riparian forest relative water level $\left(0.6 \mathrm{~m}^{3} / \mathrm{s}\right.$ at Gedinne $)$ & Indirect (based on the "riparian forest patch" layer and the validated DTM layer) \\
\hline
\end{tabular}

survey. The field survey was carried out by two operators mapping the floodplain extent based on topographic maps, local topography and vegetation. The survey was conducted using an off-the-shelf GPS receiver in the same 7 reaches of the study site as those used during the field mapping of the wetted channel extent.

\subsubsection{Evergreen coniferous stands}

In order to validate the evergreen coniferous stand layer, a photo-interpretation validation was conducted using ortho-images captured during the LiDAR survey. Three hundred interpretation points were randomly generated with ArcGIS, 100 in each class: evergreen stands, deciduous stands, and isolated trees. The quality of the classification assessment was performed using the Kappa index through a confusion matrix.

\section{Results and discussion}

\subsection{Validation results}

Compared to the field measured altimetric database, the altimetric data extracted from the LiDAR derived DTM presented a $0.14 \mathrm{~m}$ root-mean-square error (RMSE), with a mean DTM error of $0.11 \pm 0.08 \mathrm{~m}$ (mean $\pm \mathrm{SD}$ ). In contrast with the findings of previous authors (Reutebuch et al., 2003; Clark et al., 2004; Hollaus et al., 2006), these values suggest the very good quality of the DTM used in this study.

The mean distance between the LiDAR wetted channel extent and the field measured wetted channel extent (1418 points) was $-0.71 \mathrm{~m}$ (based on signed values) and $0.89 \mathrm{~m}$ (based on absolute values), with a RMSE of $1.29 \mathrm{~m}$. These results show a systematic underestimation of the wetted channel extent, which is mostly due to the rasterization process (as reported by Höfle et al. (2009)). The overall classification accuracy is $76.8 \%$, with very high user's accuracy value (97.7\%) and lower producer's accuracy value (78.1\%).

The mean distance between the LiDAR derived and the field measured floodplain extent of $5.52 \mathrm{~m}$ (based on absolute values) and $6.02 \mathrm{~m}$ (based on signed values) shows a systematic overestimation. Regarding to the extent of the floodplain (width ranging from $55 \mathrm{~m}$ to $540 \mathrm{~m}$ ), these values were suitable for our purpose, as the floodplain extent was used to localise an area of interest.

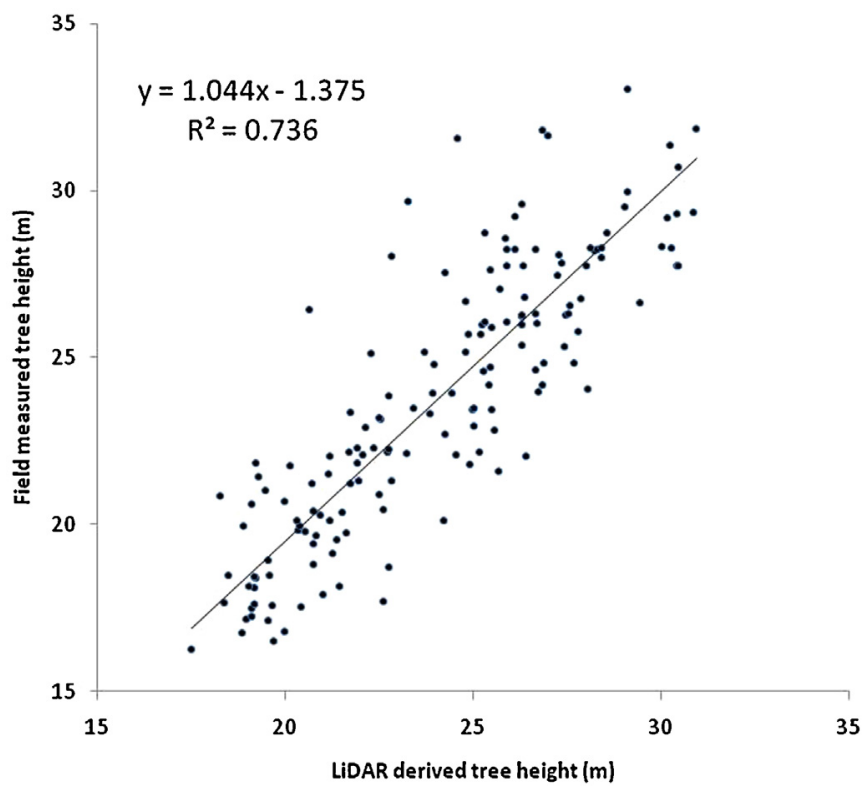

Fig. 8. Relationship between LiDAR derived $(X, \mathrm{~m})$ and field measured tree height values $(Y, \mathrm{~m})$

The CHM validation compared the height values of 159 single dominant broadleaved trees to the associated CHM raster values. We found a linear regression (Fig. 8), with the adjusted $\mathrm{R}^{2}$ being 0.74 . The mean residual, calculated by subtracting the CHM tree height values from the measured tree heights, was $-0.3 \mathrm{~m}$, showing a slight overestimation of the tree heights by the CHM. The RMSE was relatively large, $2.18 \mathrm{~m}$, but this value was similar to that found by Hollaus et al. (2006) and might be explained by operator based errors made in the field measurements. Subsequently, the quality of the LiDAR derived CHM was found to be equivalent to that noted by previous contributors (Akay et al., 2012; Clark et al., 2004; Koukoulas and Blackburn, 2005; Morsdorf et al., 2004).

The overall classification accuracy (Kappa index) of riparian forest patches reached $87.3 \%$ when the 3 classes were taken into

Table 6

Daily water mean height and daily mean discharge at Gedinne gauging station (Wallonia, Belgium) in March 2012 (field survey) compared to March 2011 (LiDAR survey).

\begin{tabular}{|c|c|c|c|c|}
\hline \multirow[t]{2}{*}{ Field survey } & \multicolumn{2}{|c|}{ Field survey (March 2012) } & \multicolumn{2}{|c|}{$\begin{array}{l}\text { Difference between LiDAR survey (March 2011) } \\
\text { and Field survey (March 2012) }\end{array}$} \\
\hline & Height (m) & Discharge $\left(\mathrm{m}^{3} / \mathrm{s}\right)$ & Height (m) & Discharge $\left(\mathrm{m}^{3} / \mathrm{s}\right)$ \\
\hline $15 / 03 / 2012$ & 0.29 & 0.88 & 0.05 & 0.32 \\
\hline $16 / 03 / 2012$ & 0.29 & 0.86 & 0.05 & 0.30 \\
\hline $21 / 03 / 2012$ & 0.26 & 0.69 & 0.02 & 0.13 \\
\hline 29/03/2012 & 0.22 & 0.48 & -0.02 & -0.08 \\
\hline Mean & 0.27 & 0.73 & 0.025 & 0.17 \\
\hline
\end{tabular}

Source: http://aqualim.environnement.wallonie.be/. 
account: "Evergreen stands", "Deciduous stands", and "Isolated trees". For the "Evergreen coniferous stand" class, the producer and user's accuracy levels were respectively 94 and $77 \%$. The accuracy levels of these classifications are within the same range as those found by Antonarakis et al. (2008), who compared five riparian forest stand types in Southern France.

\subsection{Riparian zone attributes}

Main floodplain and riparian zone attributes can be mapped at different scales. At a fine scale ( $<1 \mathrm{~km}^{2}$ frame), a classic map allows the operator to visually localise some of the main riparian and floodplain attributes (Fig. 9).

In order to establish the longitudinal pattern of the whole study site, attributes were extracted from 50-m long segments. Fig. 10 shows longitudinal channel and floodplain width pattern. Channel width increases from ca. $6 \mathrm{~m}(2 \mathrm{~km})$ to ca. $10 \mathrm{~m}(14 \mathrm{~km})$ with 2 local width peaks of ca. $15 \mathrm{~m}(16 \mathrm{~km}$ and $22 \mathrm{~km})$. Floodplain width is more complex, showing a more fluctuating width variability ranging from ca. $50 \mathrm{~m}$ to $400 \mathrm{~m}$. Very significant periodic pattern is also observed when observing continuity index along the river course whatever the buffer used or the river bank (Fig. 11A and B). Analysis at different lateral scales $(1 \mathrm{~m}, 8 \mathrm{~m}$, "floodplain", left-right bank) shows a higher level of continuity for the riparian forest patches close to the wetted channel. This parameter clearly highlights the general decrease of riparian forests when the river crosses built-up areas (italic annotations). The most significant decreases are located in the Landrichamps and Flohimont/Givet areas in France, which are the most anthropized areas within the watershed (crop field area and steel industry). Major decreases also occurred in forested areas, in clear cutting zones.

A similar longitudinal survey was also performed on three riparian forest attributes (Fig. 12). The mean riparian tree height (Fig. 12A) was found to decrease when crossing anthropized sections. This result could be interpreted as being due to more frequent vegetation maintenance (coppicing, clear cutting, etc.) of riparian trees located close to the river (wetted channel + $1 \mathrm{~m}$ scale). Nevertheless, the relative standard deviation (RSD) of the riparian tree height (Fig. 12B) did not present a specific upstream-downstream pattern.

The longitudinal pattern of overhanging (Fig. 12C and D) also underwent a reduction throughout the anthropized sections. Some river reaches with a relatively low overhanging riparian forest patch were also observed outside of these sections (within forest clear cuttings sections). No significant differences were found in human pressure from one bank to the other.

The relative area of coniferous stands (Fig. 12E) within the floodplain was not linked to the anthropized sections but did show a specific longitudinal pattern with a few sections with a significantly high density of conifers. As coniferous stand plantations are prohibited within the area of the wetted channel +1 and $+8 \mathrm{~m}$ buffers, such mapping provides information to land and water resource managers, enabling them to prioritise interventions.

The same type of analysis can be applied to the relative DEM. A mean relative height calculation was extracted for each floodplain sample at different lateral scales ( $1 \mathrm{~m}, 8 \mathrm{~m}$, "floodplain") in relation to the riparian forest patches within the sample (Fig. 13) given the relative water level of the riparian forest patches for a $0.6 \mathrm{~m}^{3} / \mathrm{s}$ discharge. Fig. 13 shows that the anthropized sections affected the topography to a lesser extent than the continuity index. Nevertheless, the relative water level (for $Q=0.6 \mathrm{~m}^{3} / \mathrm{s}$ ) within the riparian forest patches was found to increase in the anthropized sections, which could be explained by the presence of local embankments on which the riparian forest is established. Two major increases in the relative water level occurred near Landrichamps and Flohimont
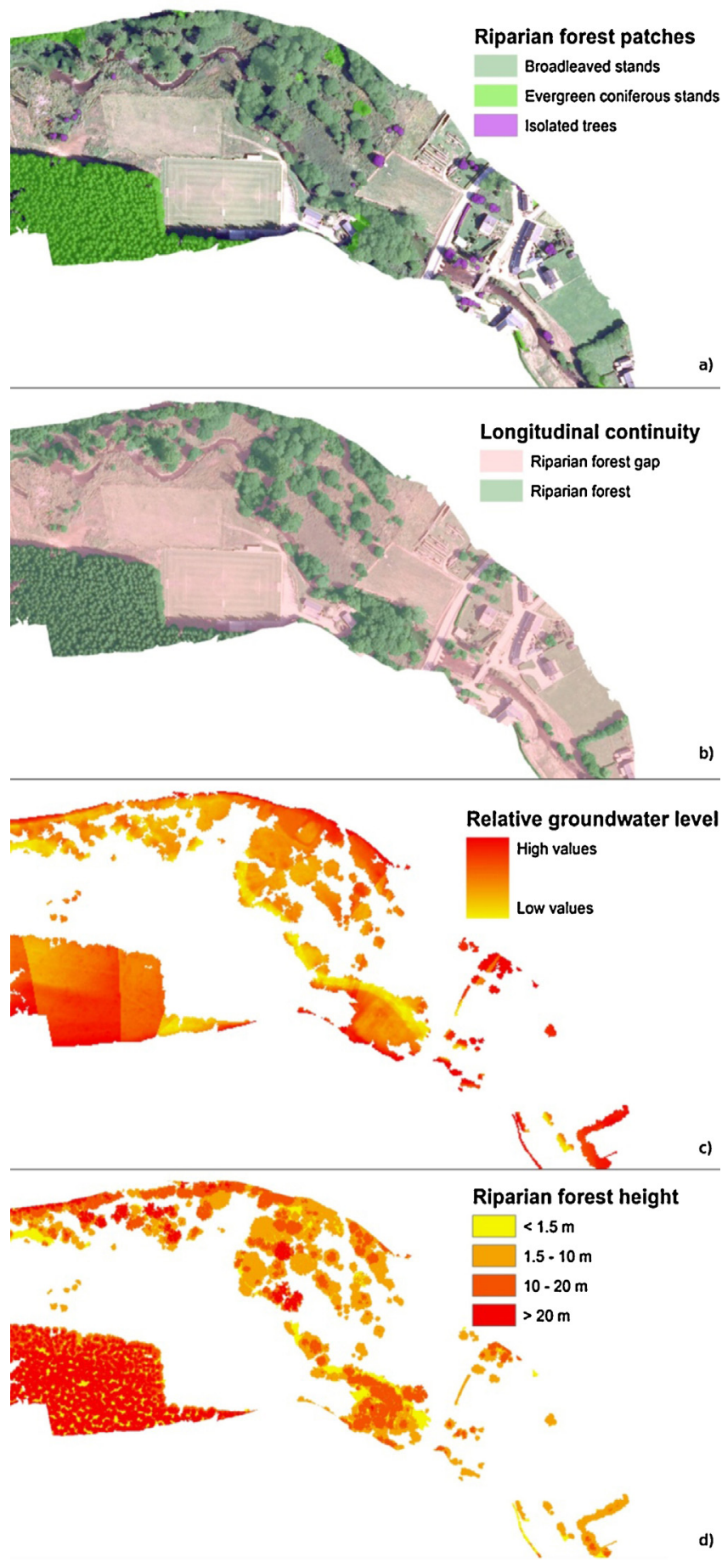

Fig. 9. Mapping riparian zone and floodplain attributes: (a) patch detection and composition; (b) longitudinal continuity; (c) relative water level; and (d) forest patch height.

(France), which represent the most anthropized zones within the watershed. Field crops were notably present within the floodplain near Landrichamps, where embankments have been commonly created to improve yields. Other agricultural areas in the floodplain are generally dedicated to cattle breeding. The floodplain is highly anthropized in Flohimont, where the steel industry is still active. Knowing the stage-discharge relationship at Gedinne, it is then possible to estimate what is the recurrence of flows overflowing the riparian patches. A discharge of $0.6 \mathrm{~m}^{3} / \mathrm{s}$ corresponds to a level of $0.24 \mathrm{~cm}$ at gage whereas $1 \mathrm{~m}$ above (ca. the 


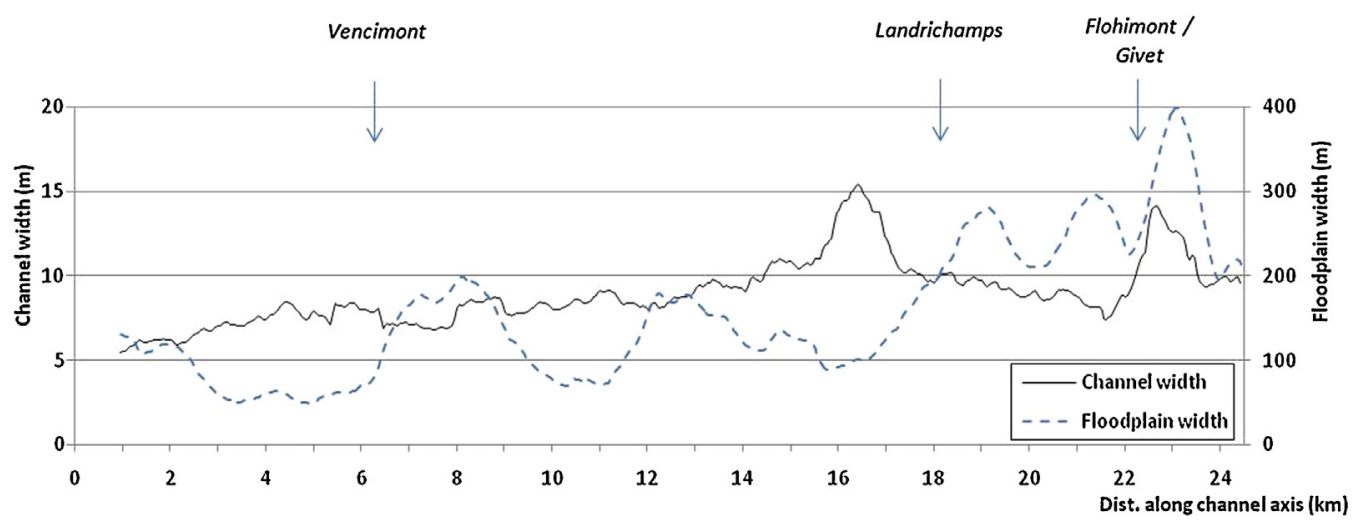

Fig. 10. Longitudinal pattern of floodplain and channel width.

bankfull level observed in the Gedinne reach between $1 \mathrm{~km}$ and $7 \mathrm{~km}$ on $8 \mathrm{~m}$ buffer on Fig. 13) would correspond to ca. $15 \mathrm{~m}^{3} / \mathrm{s}$ (ca. 1 in 10 year flood). In this reach, the riparian patches seem then infrequently flooded which may affect their riparian characters.

As an example, the detailed analysis performed every $50 \mathrm{~m}$ along the floodplain centreline to establish the longitudinal pattern can be also aggregated at a river reach scale for proposing management recommendations (Table 7). The segmentation of the river network shown in Table 7 was recently developed by the Walloon Non Navigable Watercourses Department (Burton et al., 2011), identifying homogenous river reaches (expert operator advice), with a mean length of $2.3 \mathrm{~km}$. This kind of analysis allows information to be synthesised at an appropriate scale defined by practitioners. It also highlights the important characteristics of a given reach in a stream network. In the case of the present study reach, the re-aggregated continuity index was linked to river reach typology, showing the lowest values within "Sparsely populated" reaches and maxima values within "Forest" reaches.
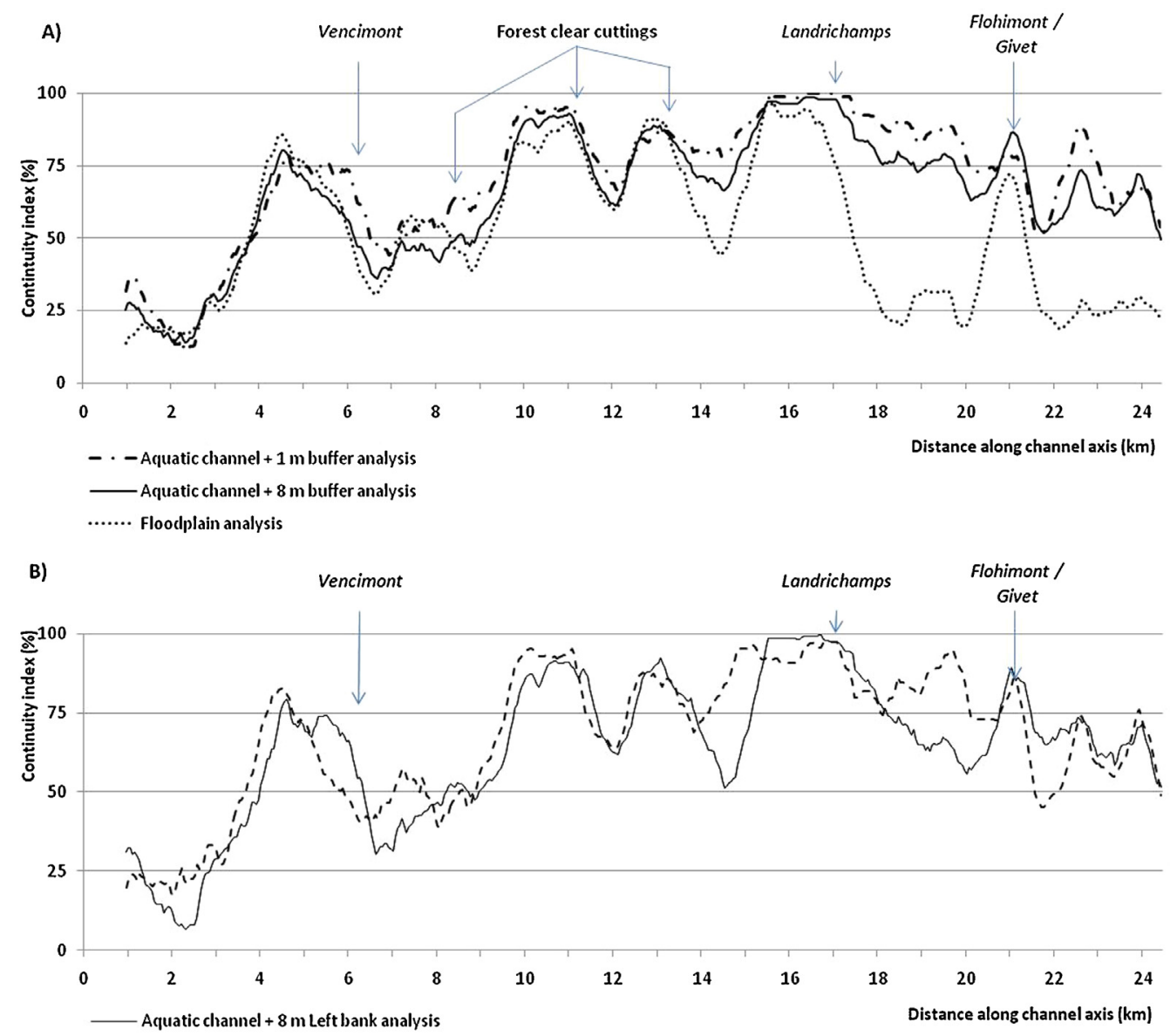

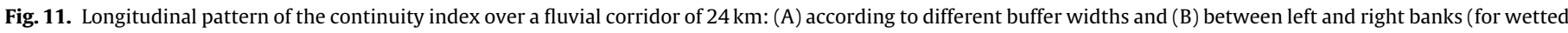
channel $+8 \mathrm{~m}$ buffer width only). 

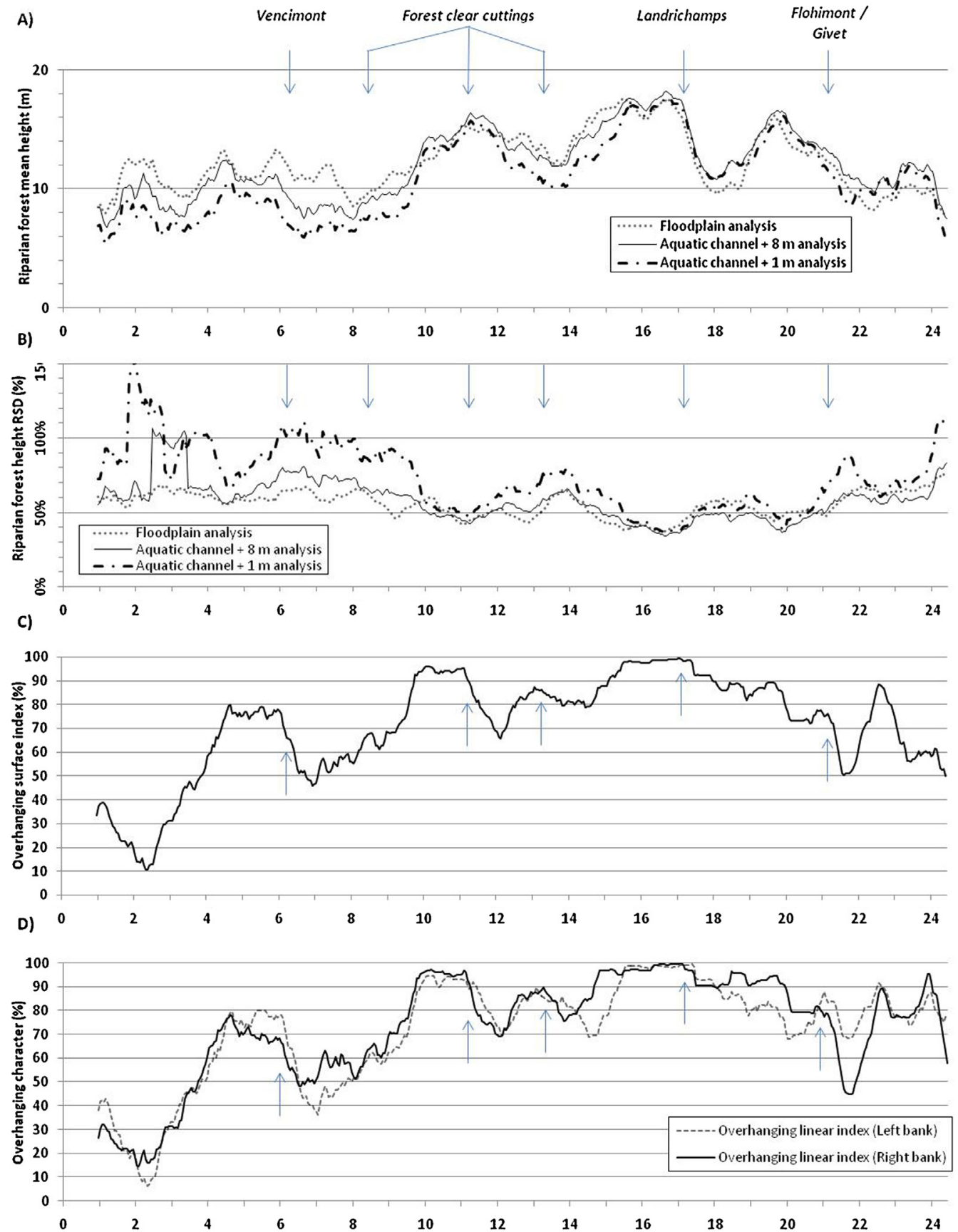

E)

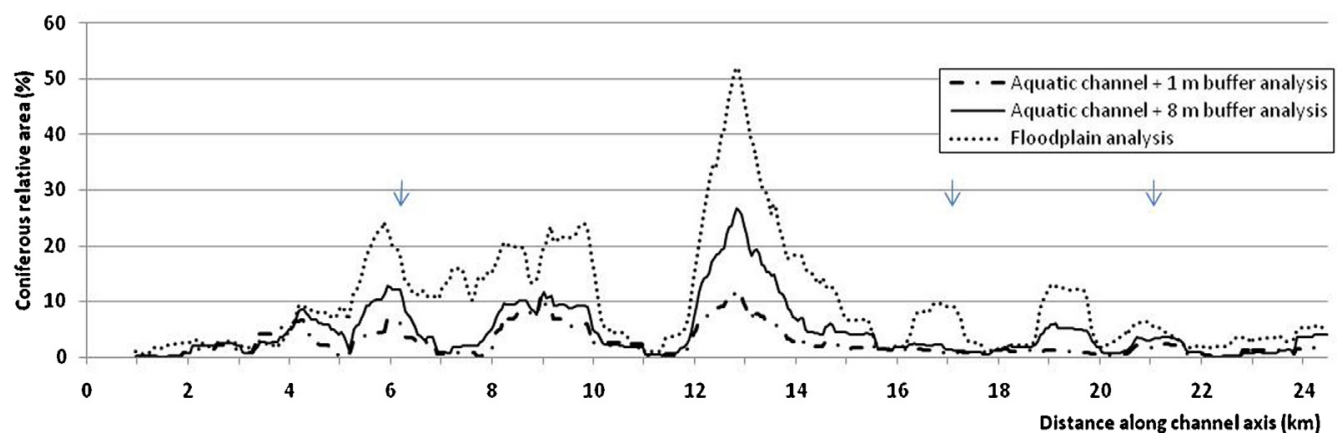

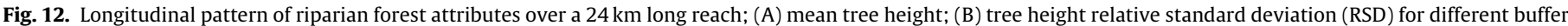

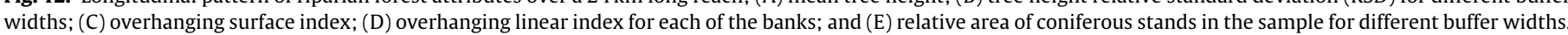




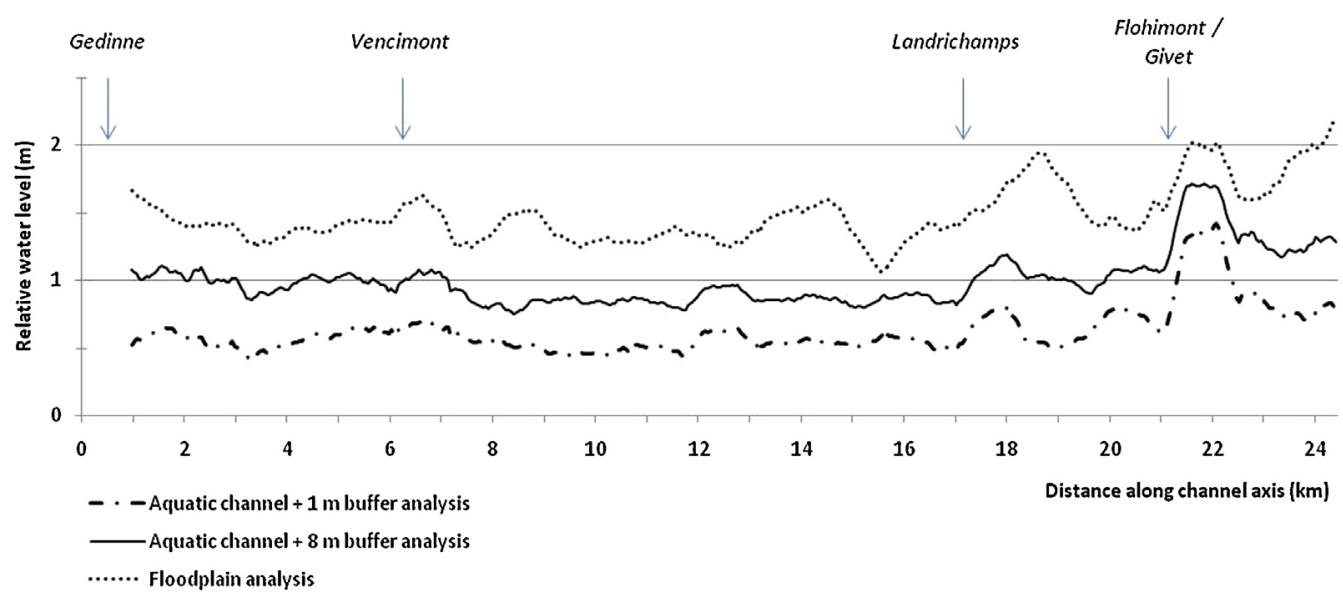

Fig. 13. Longitudinal pattern of the relative water level $(\mathrm{m})$ (in relation to riparian forest patches only for different buffer widths) at $Q=0.6 \mathrm{~m}{ }^{3}$ (Gedinne gauging station).

Table 7

Continuity index analysis: re-aggregation process at the river reach management scale; extreme values are in bold italics.

\begin{tabular}{|c|c|c|c|c|}
\hline \multirow[t]{2}{*}{ Dist. from Gedinne (km) } & \multirow[t]{2}{*}{ River reach typology } & \multicolumn{3}{|c|}{ Continuity index (\%) } \\
\hline & & $1 \mathrm{~m}$ & $8 \mathrm{~m}$ & Floodplain \\
\hline $0-0.4$ & Sparsely populated & 44 & 33 & 10 \\
\hline $0.45-5.5$ & Forest & 49 & 44 & 39 \\
\hline $5.55-6.5$ & Sparsely populated & 47 & 38 & 32 \\
\hline $6.55-8.15$ & Wetlands & 57 & 47 & 55 \\
\hline $8.2-8.85$ & Green space & 56 & 45 & 29 \\
\hline $8.9-12$ & Forest & 86 & 82 & 75 \\
\hline $12.05-15.05$ & Forest & 86 & 81 & 74 \\
\hline $15.1-18.75$ & Forest/agricultural & 93 & 86 & 46 \\
\hline $18.8-19.95$ & Forest/agricultural & 76 & 64 & 25 \\
\hline $20-24.4$ & Industrial/urban & 65 & 62 & 33 \\
\hline
\end{tabular}

\section{Conclusion}

The OBIA approach combined with classic geoprocessings allows the automated mapping of important floodplain and riparian zone attributes from aerial LiDAR data. The automated mapping of such attributes represents a major area of interest in river management and planning. At the channel scale, the study of these attributes allows accurate mapping of the wetted channel extent and overhanging riparian forests. At the riparian zone scale up to the whole floodplain scale, these attributes can provide accurate information on riparian forests and their ecological integrity: longitudinal continuity, structure (height), specific composition (coniferous stand localisation) and relative water level (e.g. flooding frequency and groundwater availability).

The graphical presentation of attributes allows natural resource managers to visualise the variation of upstream-downstream attributes. This approach combined with multi-lateral scale analysis allows relevant management units to be differentiated and priority action areas to be identified. At a network scale, the information can be gathered via a re-aggregation procedure at a given reach scale, depending on the level of accuracy required.

Our approach also permits to identify tools that can objectively and quantitatively asses some riparian zone key functionalities at the local river reach to the network scale, e.g. ecological corridor and biofilter (longitudinal continuity analysis) or shading effect and habitats improving (overhanging character analysis).

Our study shows that LiDAR data can be used to extract indicators of ecological integrity of riparian zone in temperate climate zone, where riparian zone shows less contrast to the surrounding vegetation and environments than in dryer climatic conditions. Considering the increasing availability of LiDAR data, our results highlight the potential of the approach as a tool for the planning of land and water resource management in large extent. In the European context of the Water Frame Directive, that kind of approach could improve the hydromorphological assessment of water bodies with precise information on the riparian zone and riparian forest.

In the specific case of southern Belgium, where LiDAR dataset coverage will become available in 2013, future studies will focus on a larger scale and will focus on comparisons of different types of watershed. Automatic re-aggregation procedures will be used to identify homogeneous reaches, such as the Hubert homogeneity tests (Hubert et al., 1989) as proposed by Leviandier et al. (2012). The study of different types of watershed will allow the calibration of the indicators and thus enable the assessment of the ecological integrity of riparian zone to be undertaken at the regional scale $(13,000 \mathrm{~km}$ for Wallonia, Southern Belgium).

\section{Acknowledgements}

The authors would like to acknowledge the Walloon Public Service (Walloon Non Navigable Watercourses Department) who provided financial support for the conduct of the research. Authors also thank Mr Frédéric Henrotay for his help and the anonymous reviewers for their advises.

\section{Appendix A. Supplementary data}

Supplementary data associated with this article can be found, in the online version, at http://dx.doi.org/10.1016/j. ecolind.2013.06.024. These data include Google map location of the study site. 


\section{References}

Akasheh, O.Z., Neale, C.M.U., Jayanthi, H., 2008. Detailed mapping of riparian vegetation in the middle Rio Grande River using high resolution multi-spectral airborne remote sensing. J. Arid Environ. 72, 1734-1744.

Akay, A., Wing, M., Sessions, J., 2012. Estimating structural properties of riparian forests with airborne lidar data. Int. J. Remote Sens. 33, 7010-7023.

Alber, A., Piégay, H., 2011. Spatial disaggregation and aggregation procedures for characterizing fluvial features at the network-scale: application to the Rhône basin (France). Geomorphology 125, 343-360.

Antonarakis, A.S., Richards, K.S., Brasington, J., 2008. Object-based land cover classification using airborne LiDAR. Remote Sens. Environ. 112, 2988-2998.

Barton, D.R., Taylor, W.D., Biette, R.M., 1985. Dimensions of riparian buffer strips required to maintain trout habitat in southern Ontario streams. N. Am. J. Fish. Manage. 5, 364-378.

Beschta, R.L., Bilby, R.E., Brown, G.W., Holtby, L.B., Hofstra, T.D., 1987. Stream temperature and aquatic habitat: fisheries and forestry interactions. In: Streamside Management: Forestry and Fishery Interactions 57, pp. 191-232.

Booth, D.T., Cox, S.E., Simonds, G., 2007. Riparian monitoring using 2-cm GSD aerial photography. Ecol. Indicat. 7, 636-648.

Burton, C., Henrotay, F., Claessens, H., 2011. Sectorisation des cours d'eau de 2 et 3ème catégorie de la Région wallonne - Rapport final (Rapport de convention GXABT - DCENN).

Clark, M.L., Clark, D.B., Roberts, D.A., 2004. Small-footprint lidar estimation of subcanopy elevation and tree height in a tropical rain forest landscape. Remote Sens. Environ. 91, 68-89.

Cockle, K.L., Richardson, J.S., 2003. Do riparian buffer strips mitigate the impacts of clearcutting on small mammals? Biol. Conserv. 113, 133-140.

Colson, T.P., Gregory, J.D., Mitasova, H., Nelson, S.A.C., 2006. Comparison of stream extraction models using LIDAR DEMs. In: Geographic Information Systems and Water Resources IV. American Water Resources Association Spring Specialty Conference, May 8-10, pp. 1-7.

Congalton, R.G., Birch, K., Jones, R., Schriever, J., 2002. Evaluating remotely sensed techniques for mapping riparian vegetation. Comput. Electron. Agric. 37, 113-126.

Darveau, M., Labbé, P., Beauchesne, P., Bélanger, L., Huot, J., 2001. The use of riparian forest strips by small mammals in a boreal balsam fir forest. Forest Ecol. Manage. $143,95-104$

Decamps, H., Joachim, J., Lauga, J., 1987. The importance for birds of the riparian woodlands within the alluvial corridor of the river garonne, S.W. France. Regul. River. Res. Manage. 1, 301-316.

Del Tánago, M.G., de Jalón, D.G., 2006. Attributes for assessing the environmental quality of riparian zones. Limnetica $25,389-402$.

Dowling, R., Accad, A., 2003. Vegetation classification of the riparian zone along the Brisbane River, Queensland, Australia, using light detection and ranging (lidar) data and forward looking digital video. Can. J. Remote Sens. 29, 556-563.

Eau France, 2012. Banque HYDRO [WWW Document]. http://www.hydro. eaufrance.fr/ (accessed 11.29.12)

European Council, 2000. Directive 2000/60/EC of the European Parliament and of the Council of 23 October 2000 establishing a framework for community action in the field of water policy.

Farid, A., Goodrich, D.C., Bryant, R., Sorooshian, S., 2008. Using airborne lidar to predict Leaf Area Index in cottonwood trees and refine riparian water-use estimates. J. Arid Environ. 72, 1-15.

Farid, A., Goodrich, D.C., Sorooshian, S., 2006. Using airborne lidar to discern age classes of cottonwood trees in a riparian area. West. J. Appl. Forest. 21, 149-158.

Fensham, R.J., Fairfax, R.J., 2002. Aerial photography for assessing vegetation change: a review of applications and the relevance of findings for Australian vegetation history. Aust. J. Bot. 50, 415-429.

Goetz, S.J., Wright, R.K., Smith, A.J., Zinecker, E., Schaub, E., 2003. IKONOS imagery for resource management: tree cover, impervious surfaces, and riparian buffer analyses in the mid-Atlantic region. Remote Sens. Environ. 88, 195-208.

Greenberg, J.A., Hestir, E.L., Riano, D., Scheer, G.J., Ustin, S.L., 2012. Using LiDAR data analysis to estimate changes in insolation under large-scale riparian deforestation. J. Am. Water Resour. Assoc. 48 (5), 939-948.

Hall, R.K., Watkins, R.L., Heggem, D.T., Jones, K.B., Kaufmann, P.R., Moore, S.B., Greg ory, S.J., 2009. Quantifying structural physical habitat attributes using LIDAR and hyperspectral imagery. Environ. Monit. Assess. 159, 63-83.

Hannon, S.J., Paszkowski, C.A., Boutin, S., DeGroot, J., Macdonald, S.E., Wheatley, M., Eaton, B.R., 2002. Abundance and species composition of amphibians, small mammals, and songbirds in riparian forest buffer strips of varying widths in the boreal mixedwood of Alberta. Can. J. Forest Res. 32, 1784-1800.

Hilldale, R.C., Raff, D., 2008. Assessing the ability of airborne LiDAR to map river bathymetry. Earth Surf. Process. Landf. 33, 773-783.

Hilty, J., Merenlender, A., 2004. Use of riparian corridors and vineyards by mammalian predators in Northern California. Conserv. Biol. 18, 126-135.

Höfle, B., Vetter, M., Pfeifer, N., Mandlburger, G., Stötter, J., 2009. Water surface mapping from airborne laser scanning using signal intensity and elevation data. Earth Surf. Process. Landf. 34, 1635-1649.

Hohenthal, J., Alho, P., Hyyppä, J., Hyyppä, H., 2011. Laser scanning applications in fluvial studies. Progr. Phys. Geogr. 35, 782-809.

Hollaus, M., Wagner, W., Eberhöfer, C., Karel, W., 2006. Accuracy of largescale canopy heights derived from LiDAR data under operational constraints in a complex alpine environment. ISPRS J. Photogramm. Remote Sens. 60 323-338.

Hubert, P., Carbonnel, J.P., Chaouche, A., 1989. Segmentation des séries hydrométéorologiques - application à des séries de précipitations et de débits de l'afrique de l'ouest. J. Hydrol. 110, 349-367.

Hughes, 2003. The Flooded Forest: Guidance for policy makers and river managers in Europe on the restoration of floodplain forests. FLOBAR2 Project.

Innis, S.A., Naiman, R.J., Elliott, S.R., 2000. Indicators and assessment methods for measuring the ecological integrity of semi-aquatic terrestrial environments. Hydrobiologia 422-423, 111-131.

Johansen, K., Phinn, S., 2006. Mapping structural parameters and species composition of riparian vegetation using Ikonos and Landsat ETM+ data in Australian tropical savannahs. Photogramm. Eng. Remote Sens. 72, 71-80.

Johansen, K., Tiede, D., Blaschke, T., Arroyo, L.A., Phinn, S., 2011. Automatic geographic object based mapping of streambed and riparian zone extent from LiDAR data in a temperate rural urban environment, Australia. Remote Sens. 3, 1139-1156.

Johansen, K., Arroyo, L.A., Armston, J., Phinn, S., Witte, C., 2010. Mapping riparian condition indicators in a sub-tropical savanna environment from discrete return LiDAR data using object-based image analysis. Ecol. Indicat. 10 (4), 796-807.

Johansson, M.E., Nilsson, C., Nilsson, E., Johansson, M.E., Nilsson, C., Nilsson, E., 1996 Do rivers function as corridors for plant dispersal? Do rivers function as corridors for plant dispersal? J. Veg. Sci. 7 (7), 593-598.

Karr, J.R., Dudley, D.R., 1981. Ecological perspective on water quality goals. Environ. Manage. 5, 55-68.

Kinzel, P.J., Wright, C.W., Nelson, J.M., Burman, A.R., 2007. Evaluation of an experimental LiDAR for surveying a shallow, braided, sand-bedded river. J. Hydraul. Eng. 133, 838-842.

Koukoulas, S., Blackburn, G.A., 2005. Mapping individual tree location, height and species in broadleaved deciduous forest using airborne LIDAR and multi-spectral remotely sensed data. Int. J. Remote Sens. 26, 431-455

Lecomte, H., Florkin, P., Morimont, J.-P., Thirion, M., 2006. La forêt wallonne-: état de la ressource à la fin du 20ème siècle. MRW-DGRNE-DNF, Jambes.

Leviandier, T., Alber, A., Le Ber, F., Piégay, H., 2012. Comparison of statistical algorithms for detecting homogeneous river reaches along a longitudinal continuum. Geomorphology 138, 130-144

Lonard, R., Judd, F., Everitt, J., Escobar, D., Davis, M., Crawford, M., Desai, M., 2000 Evaluation of color-infrared photography for distinguishing annual changes in riparian forest vegetation of the lower Rio Grande in Texas. Forest Ecol. Manage. 128, 75-81.

Machtans, C.S., Villard, M.-A., Hannon, S.J., 1996. Use of riparian buffer strips as movement corridors by forest birds. Conserv. Biol. 10 1366-1379.

Malanson, G., 1993. Riparian Landscapes. Cambridge University Press, Cambridge (UK).

Morsdorf, F., Meier, E., Kötz, B., Itten, K.I., Dobbertin, M., Allgöwer, B., 2004. LIDARbased geometric reconstruction of boreal type forest stands at single tree level for forest and wildland fire management. Remote Sens. Environ. 92, 353-362.

Myers, L., 1989. Riparian area management. Inventory and monitoring of riparian areas.

Naiman, R., Décamps, H., 1990. The Ecology and Management of Aquaticterrestrial Ecotones. PARTHENON Publishing Group Incorporated, Carnforth (UK).

Naiman, R., Décamps, H., McClain, M.E., 2005. Riparia: Ecology, Conservation, and Management of Streamside Communities. Elsevier Academic Press, New-York (USA)

Naiman, R., Decamps, H., Pollock, M., 1993. The role of riparian corridors in maintaining regional biodiversity. Ecol. Appl. 3, 209-212.

Narumalani, S., Zhou, Y., Jensen, J.R., 1997. Application of remote sensing and geographic information systems to the delineation and analysis of riparian buffer zones. Aquat. Bot. 58, 393-409.

Notebaert, B., Verstraeten, G., Govers, G., Poesen, J., 2009. Qualitative and quantitative applications of LiDAR imagery in fluvial geomorphology. Earth Surf. Process. Landf. 34, 217-231.

Petit, F. 1992. L'influence des plantations de resineux en fond de vallee sur l'evolution geomorphologique de rivieres de Haute-Belgique. In: International Symposium. Impacts of Watercourse Improvements. Assessment, Methodology, Management Assistance, 10-12 September, Wepion, Belgium.

Piégay, H., Pautou, G., Ruffinoni, C., 2003. Les forêts riveraines des cours d'eau: écologie, fonctions et gestion. Forêt privée française, Paris (France).

Platts, W.S., Lienkaemper, G.W., Amour, C., Minshall, G.W., Booth, G.D., Monsen, S.B. Bufford, J.L., 1987. Methods for evaluating riparian habitats with applications to management.

Pollock, M.M., Naiman, R.J., Hanley, T.A., 1998. Plant species richness in riparian wetlands - a test of biodiversity theory. Ecology 79, 94-105.

Reutebuch, S.E., McGaughey, R.J., Andersen, H.E., Carson, W.W., 2003. Accuracy of a high-resolution lidar terrain model under a conifer forest canopy. Can. J. Remote Sens. 29 (5), 527-535.

Rodriguez-Iturbe, I., Muneepeerakul, R., Bertuzzo, E., Levin, S.A., Rinaldo, A, 2009. River networks as ecological corridors: a complex systems perspective for integrating hydrologic, geomorphologic, and ecologic dynamics. Water Resour. Res. $45, \mathrm{n} / \mathrm{a}-\mathrm{n} / \mathrm{a}$.

Schneider, J.B., 2007. Plaidoyer pour une restauration des cordons rivulaires naturels des ruisseaux et ruisselets forestiers. Forêt Wallonne 86, 43-57. 
Service Public de Wallonie, 2012. AOUALIM [WWW Document]. http://aqualim. environnement.wallonie.be/ (accessed 11.29.12).

Shirvell, C.S., 1990. Role of instream rootwads as juvenile coho salmon (Oncorhynchus kisutch) and steelhead trout (O. mykiss) cover habitat under varying streamflows. Can. J. Fish. Aqua. Sci. 47, 852-861.

Skagen, S.K., Kelly, J.F., van Riper, C., Hutto, R.L., Finch, D.M., Krueper, D.J., Melcher, C.P., 2005. Geography of spring landbird migration through riparian habitats in southwestern north America. Condor 107, 212-227.

Skagen, S.K., Melcher, C.P., Howe, W.H., Knopf, F.L., 1998. Comparative use of riparian corridors and oases by migrating birds in Southeast Arizona. Conserv. Biol. 12, 896-909.
Tewksbury, J.J., Black, A.E., Nur, N., Saab, V.A., Logan, B.D., Dobkin, D.S., 2002. Effects of anthropogenic fragmentation and livestock grazing on western riparian bird communities. Stud. Avian Biol. 25, 158-202.

Wasser, L. Day, R., Chasmer, L. Taylor, A., 2013. Influence of vegetation structure on Lidar-derived canopy height and fractional cover in forested riparian buffers during leaf-off and leaf-on conditions. PLoS ONE 8 (1), e54776.

Weber, R.M., Dunno, G.A., 2001. Riparian vegetation mapping and image processing techniques, Hopi Indian Reservation, Arizona. Photogramm. Eng. Remote Sens. 67, 179-186.

Whitaker, D.M., Carroll, A.L., Montevecchi, W.A., 2000. Elevated numbers of flying insects and insectivorous birds in riparian buffer strips. Can. J. Zool. 78, 740-747. 